\title{
Two extremes of the clinical spectrum of conjunctival squamous cell carcinoma presenting in the same patient
}

\author{
Ivo Gama, ${ }^{1}$ Leonor Almeida, ${ }^{1}$ Helena Fialho, ${ }^{2}$ Conceição Crujo ${ }^{3}$
}

'Department of

Ophthalmology, University Hospital Santa Maria, Medical Faculty of Lisbon, Lisbon, Portugal

${ }^{2}$ Department of

Ophthalmology, University Hospital Santa Maria, Lisbon, Portugal

${ }^{3}$ Department of Anatomical Pathology, University Hospital Santa Maria, Medical Faculty of Lisbon, Lisbon, Portugal

\section{Correspondence to} Dr Ivo Filipe Gama, ivogama20@hotmail.com

Accepted 15 January 2017
CrossMark

$$
\begin{aligned}
& \text { To cite: Gama I, Almeida L, } \\
& \text { Fialho H, et al. BMJ Case } \\
& \text { Rep Published online: } \\
& \text { [please include Day Month } \\
& \text { Year] doi:10.1136/bcr-2016- } \\
& 217976
\end{aligned}
$$

\section{DESCRIPTION}

A black man aged 61 years with AIDS presented in our institution in 2013 with extensive left-sided orbital soft tissue necrosis and exposure of deep orbital structures, with left eye (LE) destruction

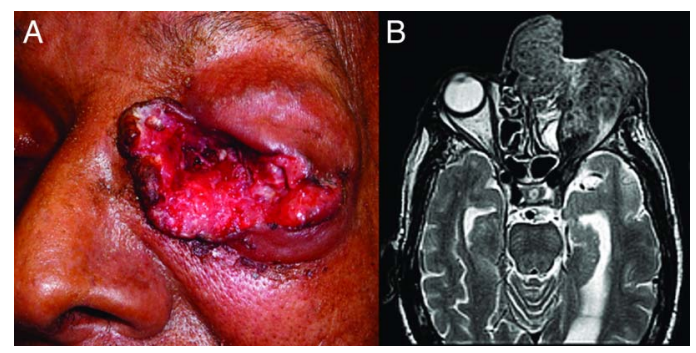

Figure 1 Photography (A) showing left-sided ulceration and destruction of the eyelids and left ocular globe, with extensive orbital soft tissue necrosis. T2-weighted MRI (B) demonstrated total left orbital invasion, with extension to paranasal sinuses, extensive bone destruction and extension to cavernous sinus. caused by squamous cell carcinoma (SCC) (figure 1A). He had a history of biopsy-proven conjunctival SCC in LE, diagnosed in 2010. T2-weighted MRI demonstrated total left orbital invasion (figure 1B), with extension to paranasal sinuses, extensive bone destruction and extension to cavernous sinus. Oncologists decided to treat with palliative radiotherapy (RT, 20 Gy in 5 fractions) followed by orbital exenteration. Ophthalmological evaluation showed suspicious conjunctival lesions with corneal invasion and a gelatinous appearance in the right eye (RE), highly atypical for pterygium (figure 2A). Excisional biopsy was performed and the histological examination showed in situ SCC (figure 2B, C). The patient was treated with adjuvant topical mitomycin $0.04 \%$ in the RE. The patient died shortly after completing the RT treatment, from extensive brain infiltration by SCC. This is a clinical case of bilateral SCC in an AIDS patient, presenting simultaneously in the two opposite poles in the clinical spectrum of the disease, which is also a rare occurrence. In the era of highly effective antiretroviral treatment, this scenario (T4 stage) is rare in

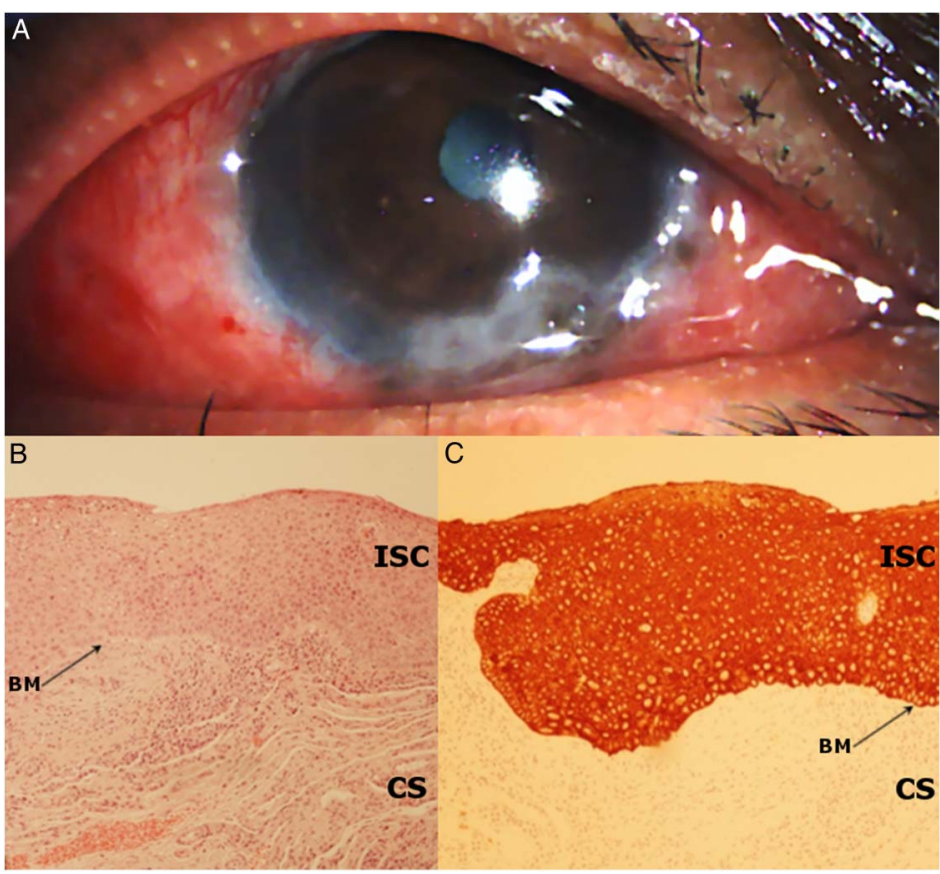

Figure 2 Slit lamp photography of the right eye (RE) at low magnification and with diffuse illumination (A), showing suspicious nasal and inferior perilimbal conjunctival lesions, with a gelatinous appearance, invading the corneal periphery. Histological examination with H\&E staining at 100x magnification (B) showed an in situ conjunctival squamous cell carcinoma (ISC) with keratinization. The full-thickness of the epithelium was replaced by dysplastic cells of the ISC, which did not pass through the basement membrane (BM) and did not invade the conjunctival stroma (CS) or substantia propria. Cytokeratin-AE1 \AE3 immunostaining (100x magnification) showed the absence of an invasive component, as the stroma (CS) was not involved (C). 


\section{Learning points}

- Squamous cell carcinoma in patients with AIDS is more aggressive, frequently multifocal and rapidly progressive and has a higher risk of intraocular penetration and destruction, which can cause a catastrophic presentation, such as the presented one.

- Every conjunctival lesion in patients with AIDS should be biopsied to rule out ocular surface squamous neoplasia and a high index of suspicion is necessary for early diagnosis. Early diagnosis and treatment are fundamental to prevent disease progression to the T4 stage.

- If conjunctival cell carcinoma is diagnosed in one eye, the other eye must be inspected promptly to rule out the disease, because patients with AIDS have a higher risk of bilateral presentation.

developed countries. ${ }^{1-3}$ In AIDS, the disease presents quite differently: it is aggressive, more often bilateral, and multifocal with intraocular penetration. ${ }^{1}$ Early diagnosis and adequate treatment in an initial stage, as occurred in RE, is fundamental, with regular follow-up to prevent disease progression to the final catastrophic stage.

Contributors All authors participated in this work. IG, LA and HF were involved in the patient care. CC was responsible for all the histological exams and for reporting of their results. IG participated in the review of the clinical records and in manuscript drafting. LA approved the final version of the manuscript to be submitted for publication.

Competing interests None declared.

Patient consent Obtained.

Provenance and peer review Not commissioned; externally peer reviewed.

\section{REFERENCES}

1 Gichuhi S, Irlam JH. Interventions for squamous cell carcinoma of the conjunctiva in HIV-infected individuals. Cochrane Database Syst Rev 2013;(2):CD005643.

2 Pe'er J, Frucht-Pery J. Conjunctival and corneal tumors: ocular surface squamous neoplasia. In: Pe'er J, Singh A. Clinical ophthalmic oncology: eyelid and conjunctival tumors. Springer, 2014:161-74.

3 Tunc M, Char DV, Crawford B, et al. Intraepithelial and invasive squamous cell carcinoma of the conjunctiva: analysis of 60 cases. $\mathrm{Br} J$ Ophthalmol 1999:83:98-103.

Copyright 2017 BMJ Publishing Group. All rights reserved. For permission to reuse any of this content visit http://group.bmj.com/group/rights-licensing/permissions.

BMJ Case Report Fellows may re-use this article for personal use and teaching without any further permission.

Become a Fellow of BMJ Case Reports today and you can:

- Submit as many cases as you like

- Enjoy fast sympathetic peer review and rapid publication of accepted articles

- Access all the published articles

- Re-use any of the published material for personal use and teaching without further permission

For information on Institutional Fellowships contact consortiasales@bmjgroup.com

Visit casereports.bmj.com for more articles like this and to become a Fellow 